\title{
Separation of Ni (II) from Industrial Wastewater by Kombucha Scoby as a Colony Consisted from Bacteria and Yeast: Kinetic and Equilibrium Studies
}

\author{
Seyyed Mojtaba Mousavi, ${ }^{1,2}$ Seyyed Alireza Hashemi, ${ }^{1,2}$ Aziz Babapoor, ${ }^{3}$ \\ Amir Savardashtaki, ${ }^{4}$ Hossein Esmaeili, ${ }^{5}$ Yaghoub Rahnema, ${ }^{1,2}$ Fatemeh Mojoudi, ${ }^{6}$ \\ Sonia Bahrani, ${ }^{1,2}$ Sara Jahandideh ${ }^{7}$ and Marziyeh Asadi ${ }^{4}$ \\ ${ }^{1}$ Department of Medical Nanotechnology, School of Adanced Medical Sciences and Technologies, \\ Shiraz University of Medical Sciences, Shiraz, Iran. \\ ${ }^{2}$ Pharmaceutical Sciences Research Center, Shiraz University of Medical Sciences, Shiraz, Iran.71348-14336 \\ ${ }^{3}$ Department of Chemical Engineering, University of Mohaghegh Ardabili, Ardabil, Iran. \\ ${ }^{4}$ Department of Medical Biotechnology, School of Advanced Medical Sciences and Technologies, \\ Shiraz University of Medical Sciences, Shiraz, Iran. \\ ${ }^{5}$ Department of Chemical Engineering, Islamic Azad University of Bushehr, Bushehr, Iran. \\ ${ }^{6}$ Department of Environment, Faculty of Natural Resources, College of Agriculture \& Natural Resources, \\ University of Tehran, Karaj, Iran. \\ ${ }^{7}$ Department of Chemical and Polymer Engineering, Faculty of Engineering, Yazd University, \\ Yazd, P.O. Box: 891581-8411, Iran.enia \\ *Corresponding author: E-mail: mousavi.nano@gmail.com \\ Tel: +98-939-926-8875
}

Received: 01-22-2019

\begin{abstract}
Kombucha Scoby is a colony consisted from bacteria, yeast and cellulosic pellicle which has unique outcomes and performances in variety of fields. Along with antimicrobial and anti-toxicity of kombucha, it can be adapted to develop reactors for removal of heavy metals from waste water. The main objective of this study is to investigate the removal of Ni (II) ions from wastewater by Kombucha as a microorganism by considering the $\mathrm{pH}$, time, temperature, the electrolyte solution, the buffer volume and type. The adsorption experiments indicated that the maximum adsorption capacity of Ni (II) occurred at the $\mathrm{pH}$ of 7 , contact time of $15 \mathrm{~min}$ and temperature of $25^{\circ} \mathrm{C}$. In the optimal conditions, $94.5 \%$ of $\mathrm{Ni}$ (II) ions was removed from the solution, which clarify the significant effectiveness of Kombucha Scoby in matter of heavy metal removal. Besides, equilibrium experiments fitted well with the Langmuir isotherm model and the maximum Kombucha Scoby adsorption capacity at $25^{\circ} \mathrm{C}$ was determined to be a very high adsorption capacity of $454.54 \mathrm{mg} / \mathrm{g}$. Additionall, adsorption kinetic behaviour of $\mathrm{Ni}$ (II) on to the Kombucha Scoby can be described using the pseudo-second order model.
\end{abstract}

Keywords: Separation; kombucha; bacteria; adsorption kinetics; Ni (II)

\section{Introduction}

Heavy metal contamination of water is a common phenomenon which can cause variety of problems in different applications. The discharge of heavy metals into an aquatic ecosystem has become a matter of concern over the last decades. Among these serious pollutants, some contamination such as lead, chromium, mercury, uranium, selenium, zinc, arsenic, cadmium, gold, copper and nickel have significant impacts on the ecosystem. ${ }^{1}$ The 
presence of heavy metals in the environment is a major concern due to their extreme toxicity and tendency for bioaccumulation in the food chain even in relatively low concentrations. ${ }^{2}$ Researchers have put a great effort to overcome the toxicity of materials within the environment, ${ }^{3,4}$ but removal of heavy metals along with deterioration of their toxicity remains a big concern. Moreover, Nickel is a toxic heavy metal that widely used in silver refineries, electroplating, zinc base casting and storage battery industries. ${ }^{5,6}$ Furthermore, the chronic toxicity of nickel to humans and the environment have been well documented, for example, high concentration of nickel (II) within the environment can cause lung, nose and bone cancers. Therefore, it is essential to remove Ni (II) from industrial wastewater before being discharged. For this matter, it is generally used as the advanced treatment processes such as chemical reduction, ion exchange, reverse osmosis, electro-dialysis and activated carbon adsorption. In addition, usage of agricultural residues and their biological activities have received a considerable attention., In recent years, a number of agricultural materials such as moss peat, ${ }^{5,9}$ coconut husk, ${ }^{10,11}$ chitosan, ${ }^{12}$ coir pith, ${ }^{9}$ eggshell, ${ }^{13,14}$ and almond husk ${ }^{9}$ were examined in order to remove heavy metal contaminants. ${ }^{15}$ On the other hand, adsorption technique is an attractive approach for water treatment, especially if the adsorbent being costly efficient, convenient to separate and easy to regenerate. ${ }^{16}$ If the amount of heavy elements in different environments goes beyond a certain dosage, then they would be considered as contaminant sources. Moreover, great deals of heavy metals enter the environments by atmospheric subsidence, mining and agriculture. ${ }^{17}$ Besides, one of the most important sources for an increase in the concentration of heavy metals in aqueous environments is the discharge of wastewater. ${ }^{18}$ Furthermore, materials that have been widely used for removal of adsorption, not only have a high level of adsorption but also they are not soluble in water. ${ }^{17}$ Up to now, some materials such as banana peels, ${ }^{19,20}$ oranges, ${ }^{21}$ paddy rice, ${ }^{22}$ groundnuts, ${ }^{23}$ activated charcoal ${ }^{24}$ and other unimportant agricultural wastes have been used to remove heavy metals. In case of removing metals, usage of the adsorption method, extraction of metals ions with solids like bio-solid, modified silica, aluminum, activated charcoal and resin can be mentioned. ${ }^{25-28}$

Kombucha is a fermentation of sweetened tea, which provide symbiosis of acetic acid bacteria and yeast species. Kombucha Scoby (floating solid part in the liquid media) which so called "tea fungus" (i.e. symbiotic colony of bacteria and yeast $)^{29}$ is consisted from symbiosis of acetic acid bacteria, various kinds of yeasts and cellulosic pellicle. ${ }^{30,31}$ Kombucha Scoby can generate acetic acid, small quantities of ethanol and $\mathrm{CO}_{2}$. In the primary stages of fermentation, acetic acid bacteria of kombucha cannot use sucrose directly. In this matter, the yeast will degrade sucrose into the fructose and glucose which can furtherly lead to production of ethanol. ${ }^{32}$ Acetic acid bacteria and osmophilic yeasts are the dominant species during the kombucha fermentation. These species developing a cellulosic pellicle (a biofilm) floating on the fermented liquid, which can be thence transferred to another chamber for further use. Kombucha as a beneficial sweetened tea and has some therapeutic benefits (e.g. carcinogenic, anti-diabetic and detoxifying potentials and defined to be highly effective for weight loss and treatment of Cancer, AIDS, gastric ulcers and high blood cholesterol $)^{33-35}$ and provide strong antimicrobial activity against wide range of bacteria. ${ }^{35-37}$

Additionally, the yeast, ferment the added sugar in the tea medium to ethanol, which will be oxidized by the acetic acid bacteria to generate acetic acid. The outcome of this process lead to low $\mathrm{pH}$, while the presence of antimicrobial metabolites reduces the total composition of other bacteria, filamentous fungi and yeast. Moreover, analyses of fermented liquid media revealed the presence of gluconic, acetic and lactic acids as main chemical compounds in the resulting media. ${ }^{34,38}$ In fact, gluconic acid is the main therapeutic source in the kombucha and its function in the liver as a detoxification agent. ${ }^{34,39}$ Furthermore, the presence of usinic acid in the cultured kombucha can act as another source of antibacterial agent, ${ }^{40}$ while some other researcher suggested that acetic acid is the major antibacterial agent within the Kombucha culture. ${ }^{36}$

Symbiosis of bacteria and yeasts within the kombucha lead to its remarkable benefits and outcomes. Different kombucha Scoby provided from diverse sources present different outcomes, bacteria and yeast. Among frequently bacteria within the kombucha we can refer to strains of Acetobacteria (xylinum (cellulose-producing), aceti and pasteurianus), Lactobacillus and Gluconobacter. On other hand, various kinds of yeast were identified within the kombucha among we can refer to the Brettanomyces, Brettanomyces bruxellensis, Brettanomyces intermedius/Dekkera, Candida, Candida famata, Mycoderma, Mycotorula, Pichia, Pichia membranaefaciens, Saccharomyces, Saccharomyces cerevisiae, Schizosaccharomyces, Torula, Zygosaccharomyce, Zygosaccharomyces bailii and Zygosaccharomyces rouzii, Torulospora and Kloeckera. ${ }^{34,35,41-43}$

The aim of this research is to evaluate the separation of $\mathrm{Ni}$ (II) from aqueous solution using Kombucha Scoby in a batch reactor. The effect of various parameters such as namely contact time, adsorbent dose, $\mathrm{pH}$, and the initial concentration on the removal of $\mathrm{Ni}$ (II) was also investigated. Usage of this kind of materials has several advantages such as high treated water quality, low sludge production, small footprint, robustness and flexibility for future expansion. They are particularly attractive for treatment of recalcitrant wastewater, where long sludge retention times (SRT), applied for facilitating the efficient removal of slowly biodegradable pollutants. The fungus known as Kombucha is a waste produced during black fermentation. The objective of this study was to examine the main aspect of a possible strategy for the removal of arsenates by tea fungal bio reactor. 


\section{Materials and Method}

Kombucha Scoby was procured from the Caucasus Mountains. The spectrophotometric measurements were carried out with a UV-Vis spectrophotometer model Cintra 101 (GBC Scientific Equipment, Australia) at a wavelength of $546 \mathrm{~nm}$. Besides, for different stages of this study, some instruments such as $\mathrm{pH}$-meter (632Metrohm, Herisau, Switzerland), digital optical microscope (Rohs, model $\mathrm{U} 1000 \mathrm{X})$ and super magnet $(1.2 \mathrm{~T}, 10 \mathrm{~cm} \times 5 \mathrm{~cm} \times 2 \mathrm{~cm})$ were used.

\section{1. Cultivation of Kombucha Scoby}

The Kombucha tea medium was prepared via a multi-stage process. Firstly, $1 \mathrm{~L}$ distilled water boiled and thence $100 \mathrm{~g}$ white sugar along with $5.4 \mathrm{~g}$ black tea leaves added to the suspension, stirred for $5 \mathrm{~min}$ and thence the suspension was allowed to steep for $15 \mathrm{~min}$. Tea leaves were removed from sweetened tea and the resulting suspension was transferred to a sterile glass vessel. Once the suspension cooled to the room temperature $\left(25^{\circ} \mathrm{C}\right)$, it was inoculated with a small piece of kombucha Scoby. The suspension was then fed with $40 \%$ wt sugar each week till the completion of Kombucha Scoby and creation of a baby Scoby after 21 days. Thereafter, four generated Scobies were cut and transferred to the aerobic reactor to start the experimental evaluation.

\section{2. Experimental Setup and Reactor Operation}

The schematic of experimental setup shown in Figure 1. The aerobic reactor made of polypropylene (PP) (38 $\mathrm{cm}$ in diameter, $63 \mathrm{~cm}$ in height, with an operating level of $58 \mathrm{~cm}$ ) was coupled to a sub-merged cross-flow ultrafiltration (UF) flat sheet membrane module (Microdyn-Nadir $\mathrm{GmbH}$, Germany) with a total effective filtration area of $0.39 \mathrm{~m}$. This reactor consisted from 3 main parts, in the first part, the unfiltered suspension was poured into a chamber. In the second part, the suspension was passed from 4 layers of Kombucha Scoby and after that entered the third chamber. In the third chamber, suspension pumped and returned to the first chamber and this step was continued continuously for a specific period of time, a view of this bioreactor can be seen in Figure 1. Moreover, not only the biological degradation of organic pollutants is carried out in the bioreactor by adapted microorganisms, but also the separation $\mathrm{Ni}$ (II) from the treated wastewater is performed by a membrane module. In addition, the Kombucha Scoby constitute a physical barrier for all suspended solids and therefore enable not only recycling of the activated sludge to the bioreactor but also the production of permeate free of suspended matter, bacteria and viruses. Besides, usage of Kombucha Scoby to separate Ni (II) ions from the treated wastewater is the main difference

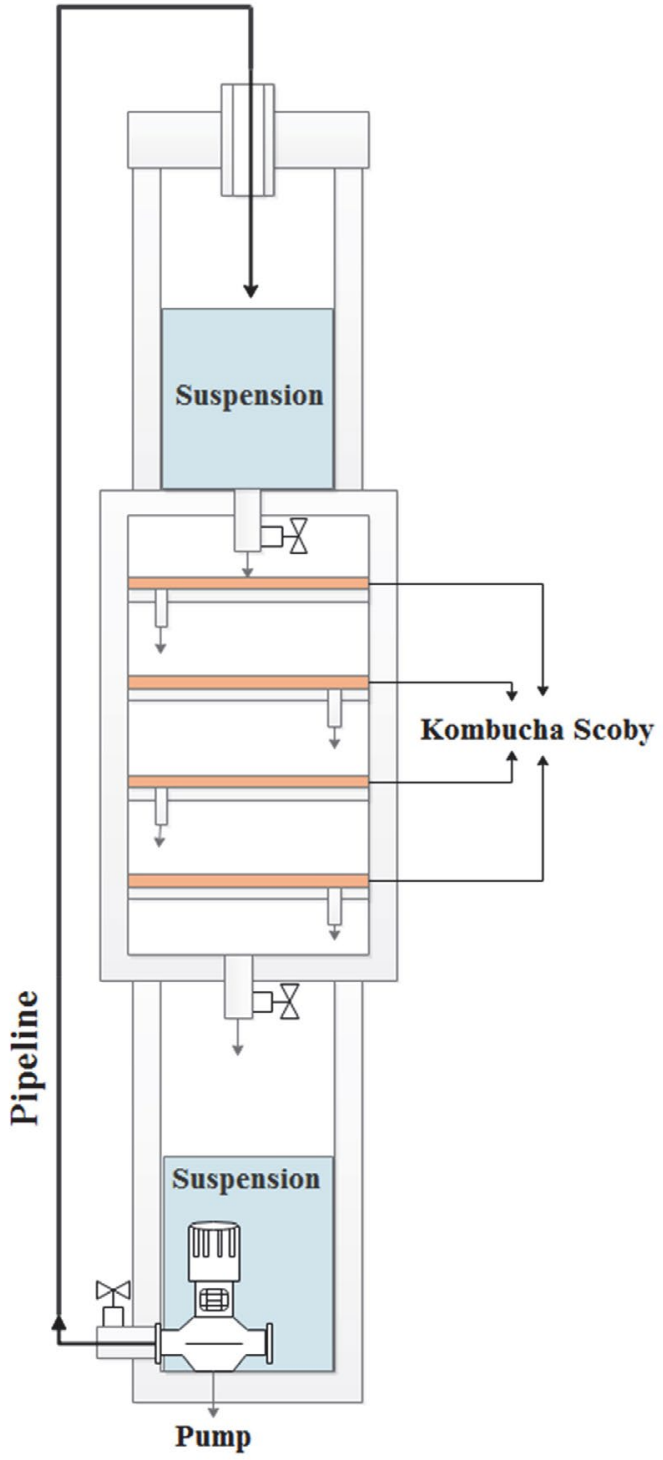

Figure 1. Schematic of experimental setup for reactor operation.

between Kombucha Scoby and traditional treatment plants for which the efficiency of the final clarification step depends mainly on the settling properties of the activated sludge.

In addition, the final ingredients vary with the bacteria and yeast in the mat, as well as the extent to which fermentation has taken place. Analyses have identified small amounts of alcohol (usually pf about 2.5\%), substantial acetic acid (vinegar), ethyl acetate, glucuronic acid and lactic acid. Besides, there is some residual sugar, depending on how long it has been fermenting. Caffeine is still present and may be responsible for some of the energy claims. Moreover, it has claimed to contain B vitamins too. Besides, the results show that usage of this kind of bacteria can lead to the removal rate of $90 \%$ after $4 \mathrm{pu}$ rification cycles in a certain period of time. Moreover, in Figure 2, microscope images of Kombucha Scoby layer can be seen. 


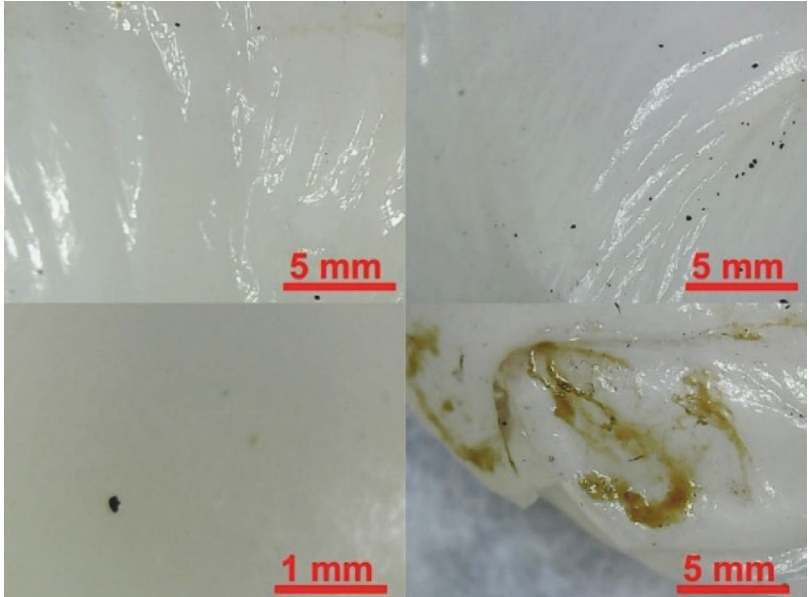

Figure 2. Optical microscopic images of Kombucha Scoby layer in different scales.

\section{3. Experimental Evaluation of Kombucha Adsorption Properties}

The adsorption experiments were performed by the batch method. Besides, $\mathrm{pH}$ value of the solutions was adjusted by using diluted solutions of $\mathrm{NaOH}$ and $\mathrm{HCl}$. Furthermore, completion of the reactor process, the resulting suspension was stirred for a defined time $(5 \mathrm{~min})$. Then, the suspension was allowed to settle by a magnet and the supernatant was analyzed for measuring the remaining $\mathrm{Ni}$. Moreover, adsorption percent of $\mathrm{Ni}$, i.e. the $\mathrm{Ni}$ removal efficiency, was determined using the following expressions:

$$
\text { (Ni) Removal Efficiency }(\%)=\frac{\mathrm{C}_{0}-\mathrm{C}_{f}}{\mathrm{C} 0} \times 100
$$

The amount of $\mathrm{Ni}$ ions adsorbed by the adsorbent was given by Eq. (2):

$$
q_{e}=\frac{\left(\mathrm{C}_{0}-\mathrm{C}_{\mathrm{f}} \mathrm{V}\right.}{\mathrm{m}}
$$

Where where $\mathrm{q}_{\mathrm{e}}$ is the amount of equilibrium adsorbed $\mathrm{Ni}^{+}$ion adsorbed by the adsorbent $\left(\mathrm{mg} \mathrm{g}^{-1}\right), C_{0}$ and $C_{f}$ represent the initial and final ion concentrations, respectively. Besides, specimens containing Ni solution were analyzed using a UV-Vis spectrophotometer at $\lambda_{\max }=577$ $\mathrm{nm}$ and all of measurements were conducted triplicate. In Figure 3, the adsorption rate of Ni nanoparticles can be seen.

\section{4. Adsorption Isotherms}

Batch adsorption applications were analyzed using Freundlich and Langmuir isotherm models. Freundlich model assumes that the uptake of adsorbate occurs on a heterogeneous surface of the adsorbent (see Figure 3). The

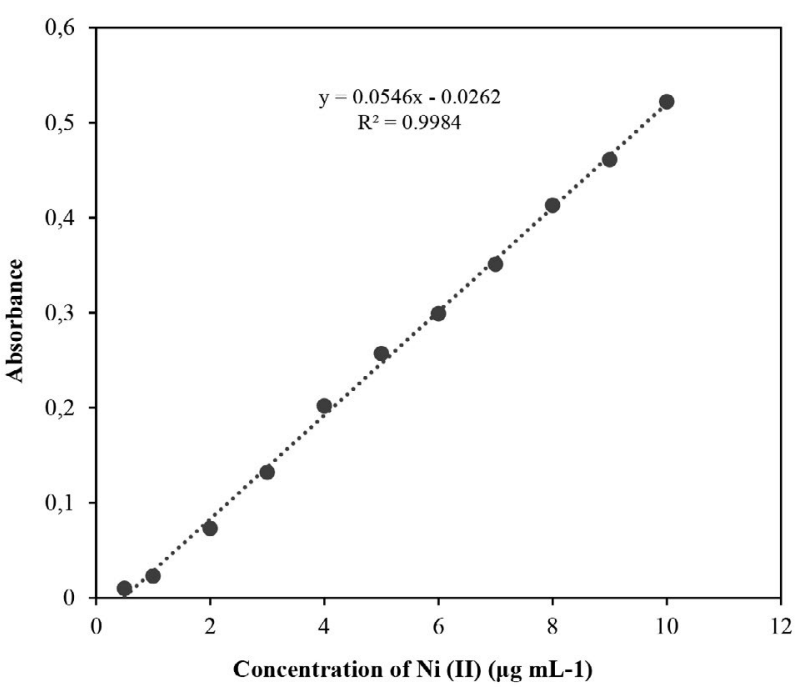

Figure 3. Ni (II) nanoparticles adsorption range.

Langmuir model describes the monolayer sorption process onto the adsorbent surface with specific binding sites. The linearized form the model equation is given as Freundlich model (Eq. 3) and linear plot of the Freundlich model is shown in Figure 4 [44].

$$
\ln \mathrm{q}_{\mathrm{e}}=1 / \mathrm{n} \ln \mathrm{C}_{\mathrm{e}}+\ln \mathrm{K}_{\mathrm{f}}
$$

In addition, Langmuir model is as follow [45]:

$$
\mathrm{C}_{\mathrm{e}} / \mathrm{q}_{\mathrm{e}}=1 / \mathrm{K}_{\mathrm{L}} \mathrm{q}_{\mathrm{m}}+\mathrm{C}_{\mathrm{e}} / \mathrm{q}_{\mathrm{m}}
$$

In Eq. (3), $\mathrm{K}_{\mathrm{f}}\left(\log ^{-1}\right)$ and $\mathrm{n}$ (dimensionless) are Freundlich isotherm constants and indicative of extended adsorbent and the degree of nonlinearity between solution concentration $(\mathrm{C})$ and adsorption $(\mathrm{q})$, respectively. Moreover, the plot of $\ln q_{e}$ versus $\ln C_{e}$ for the adsorption was employed to generate $\mathrm{K}_{\mathrm{f}}$ and $\mathrm{n}$ from the intercept and the slope values, respectively. Furthermore, in Eq. (4), $\mathrm{q}_{\mathrm{m}}$ is the monolayer adsorption capacity of the adsorption (mol . $\left.\mathrm{g}^{-1}\right)$; and $\mathrm{K}_{\mathrm{L}}$ is the Langmuir constant $\left(\mathrm{L} \mathrm{mol}^{-1}\right)$, and is related to the free energy of adsorption. Besides, the plot of $1 / \mathrm{q}_{\mathrm{e}}$ versus $1 / \mathrm{C}_{\mathrm{e}}$ for the adsorption of Ni onto modified biomass shows a straight line of slope, $1 / \mathrm{q}_{\mathrm{m}} \mathrm{K}_{\mathrm{L}}$, and intercept, $1 / \mathrm{q}_{\mathrm{m}}$. In order to determine the variability of adsorption, a dimensionless constant called as separation parameter $\left(R_{L}\right)$ was used that is defined as follow:

$$
R_{L}=\frac{1}{1+k_{l} C_{o}}
$$

Where $\mathrm{C}_{\mathrm{o}}$ is the highest initial $\mathrm{Ni}$ concentration $\left(\right.$ mol. $\left.\mathrm{L}^{-1}\right)$. The value of separation parameter indicates the shape of isotherm to be either favorable $\left(0<\mathrm{R}_{\mathrm{L}}<1\right)$, unfavorable $\left(R_{L}>1\right)$, linear $\left(R_{L}=1\right)$ or irreversible $\left(R_{L}=0\right)$ [46]. Furthermore, the linear plot of the Freundlich model can be seen in Figure 4. 


\section{5. Adsorption Kinetics}

Batch adsorption kinetics of Ni (II) uptake was examined by using the pseudo-first-order kinetic model of Lagergren and the pseudo-second-order kinetic model intra-particle diffusion model at different temperatures. The adsorption capacity $\left(\mathrm{q}_{\mathrm{t}}, \mathrm{mg} / \mathrm{g}\right)$ at any time using was calculated based on the following equation

$$
q_{t}=\frac{\left(\mathrm{C}_{0}-\mathrm{C}_{\mathrm{f}}\right) \mathrm{V}}{\mathrm{m}}
$$

where $\mathrm{C}_{0}$ and $\mathrm{Ct}\left(\mathrm{mg} \mathrm{L}^{-1}\right)$ are the concentrations of $\mathrm{Ni}$ ion at initial and any time $t$, respectively. $\mathrm{V}(\mathrm{L})$ is the solution volume and $\mathrm{m}(\mathrm{g})$ represents the mass of adsorbent.

The equation (7) shows Lagergren pseudo-first-order kinetic model and linearized pseudo-first order plots of Langmuir are illustrated in Figure 5. ${ }^{32}$

$$
\log \left(q_{e}-q_{t}\right)=\log q_{e}-\frac{k_{1} t}{2.303}
$$

In addition, the equation (8) shows Lagergren pseudo-second-order kinetic model and linearized pseudo-second order plots of Langmuir, an illustration of this plot can be seen in Figure 3. ${ }^{35}$

$$
\frac{\mathrm{t}}{\mathrm{qt}}=1 / \mathrm{k}_{2} \mathrm{q}_{\mathrm{e}}^{2}+\mathrm{t} / \mathrm{q}_{\mathrm{e}}
$$

In Eq. (7), $\mathrm{q}_{\mathrm{e}}$ and $\mathrm{q}_{\mathrm{t}}$ are the adsorption capacities of adsorbent material at equilibrium, and time $\mathrm{t}\left(\mathrm{mg} \mathrm{g}^{-1}\right)$, respectively. Besides, $\mathrm{k}_{1}$ is the rate constant for pseudo-first-order adsorption $\left(\mathrm{min}^{-1}\right)$. In Eq. (8), $\left(\mathrm{mg} \mathrm{g}^{-1}\right)$ and $k_{2}\left(\mathrm{~g} \mathrm{mg}^{-1} \mathrm{~min}^{-1}\right)$ are the maximum adsorption capacity and the equilibrium rate constant for the pseudo-second-order adsorption, respectively.

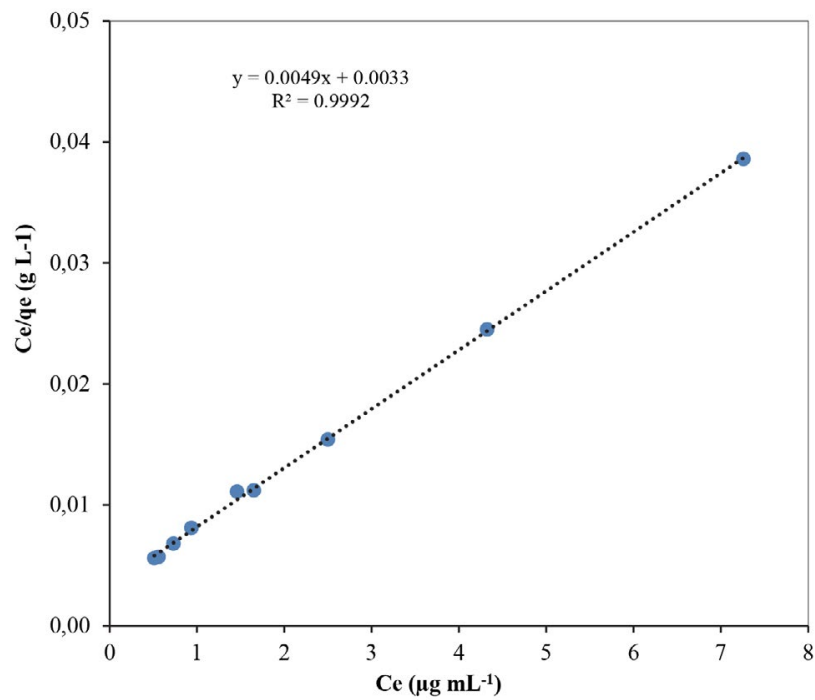

Figure 5. Linear plot of the Langmuir model.

\section{Results and Discussion}

\section{1. FTIR Investigation}

The FTIR spectra of kombucha achieved in the range of $400-4000 \mathrm{~cm}^{-1}$ which providing information about its molecular structure and respective physical-chemical properties. As shown in Figure 6, the broad adsorption band in the wavelengths interval 3000-3500 $\mathrm{cm}^{-1}$ is characteristic to $-\mathrm{OH}$ stretching vibration involved in inter and intramolecular hydrogen bonds, while peaks at $\mathrm{N}-\mathrm{H}$ group appear at around $3400 \mathrm{~cm}^{-1}$. The adsorption bands between $1636 \mathrm{~cm}^{-1}$ corresponds to $\mathrm{C}=\mathrm{O}$ stretch bands. A significant increase of the absorption band at around $1400 \mathrm{~cm}^{-1}$ assigned to the C-N stretching and the absorption band at $1362 \mathrm{~cm}^{-1}$ specific for $\mathrm{C}-\mathrm{H}$ deformation.

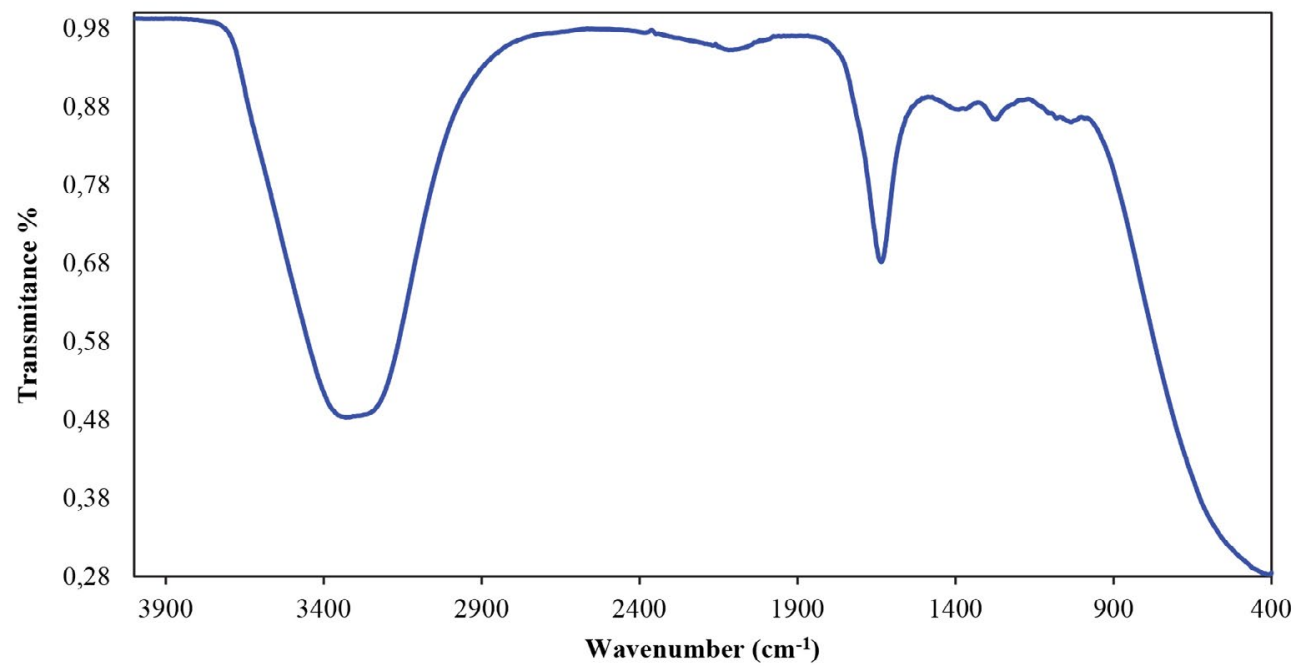

Figure 6. FT-IR study of kombucha. 


\section{2. The Effect Solution pH}

$\mathrm{pH}$ is an important parameter in the adsorption of metal ions from aqueous solutions. The effect of $\mathrm{pH}$ was conducted by mixing bio reactor of the adsorbent with 50 $\mathrm{ml} \mathrm{Ni}$ (II) solution $(20 \mathrm{mg} / \mathrm{L})$. $\mathrm{HCl}$ or $\mathrm{NaOH}$ was utilized in order to keep the $\mathrm{pH}$ in the range of 3-9 throughout the experiments. At lower $\mathrm{pH}$ values, $\mathrm{Ni}$ (II) ion removal was inhibited, because at lower $\mathrm{pH}$ 's, the medium contains a high concentration of hydrogen ions, therefore competition between $\mathrm{H}^{+}$and $\mathrm{Ni}^{2+}$ ions for the available adsorption sites could be possible. The effect of $\mathrm{pH}$ on the removal rate of $\mathrm{Ni}^{2+}$ from aqueous solution that calculated by equation 1 , is presented in the Figure 7 . As can be seen, the removal of nickel (II) ion increased with increase in the $\mathrm{pH}$ and reached a maximum at $\mathrm{pH}$ equals 7 . Besides the percentage of $\mathrm{Ni}$ removal rate was observed to be changed sharply between $\mathrm{pH} 3$ and $\mathrm{pH} 9$ (from the percentage removal of $93.6 \%$ to $66.38 \%$ ). Furthermore, at $\mathrm{pH}$ 's greater than 7, the adsorption of $\mathrm{Ni}$ (II) ions decreases due to the precipitation of nickel hydroxide, resulting from $\mathrm{Ni}$ (II) ions reacting with hydroxide ions. Moreover, the suspension was shaken for $5 \mathrm{~min}$ at the temperature of $25{ }^{\circ} \mathrm{C}$ and the optimum condition was found to be at the $\mathrm{pH}$ equals 7. In further works, the $\mathrm{pH}$ of the solutions was adjusted by using citrate buffer volume ( $\mathrm{ml})$. In addition, effect solution $\mathrm{pH}$ on $\mathrm{Ni}$ (II) ions removal rate can be seen in Figure 7.

In fact, there is a competition between nickel ions and hydrogen cation in order to occupy active sites within the absorbent. If these sites become occupied with hydrogen cation, there would be no active sites for nickel ions which can reduce the recovery of adsorption. At high $\mathrm{pH}$ values $(\mathrm{pH}>7)$, hydrogen cation content is low, while the hydroxyl $(-\mathrm{OH})$ content inside the solution is high. In this matter, there would be no competition between hydrogen cations and nickel ions, thereby the active sites become occupy with nickel ions which can improve the removal rate.

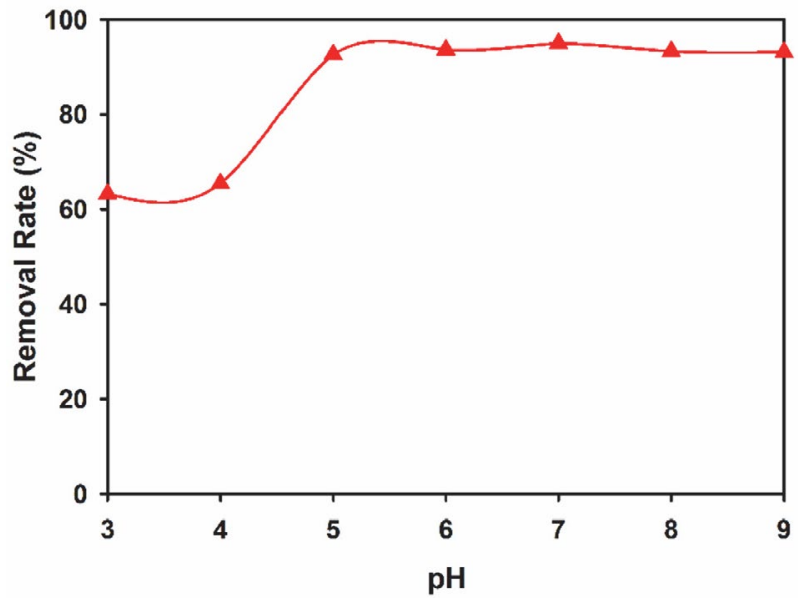

Figure 7. Effect of initial solution $\mathrm{pH}$ of $\mathrm{Ni}$ (II) ions on removal efficiency.
Moreover, at higher $\mathrm{pH}$ values, a majority of hydroxide anions create a complex with nickel ions and thence these ions deposit and accumulate in the solution.

\section{3. The Effect of Contact Time}

The effect of contact time on the performance of Kombucha Scobies in matter of Ni (II) adsorption was investigated separately. The solution $\mathrm{pH}$ and Kombucha Scoby dosage were fixed at their obtained optimum values. Figure 8 shows removal efficiencies for Ni (II) as a function of bioreactor time (in the range of 1 and $20 \mathrm{~min}$ ). According to these results, the optimum stirring time for removal by Kombucha Scoby is $15 \mathrm{~min}$. The contact time between adsorbent and adsorbent is the most important design parameter that affects the performance of adsorption processes. These data indicate that adsorption started immediately upon adding the Kombucha Scoby to the dye solution. The removal efficiency of $\mathrm{Ni}$ (II) was rapidly increased from $56.81 \%$ in the first minute of contact to 93.88 $\%$, when the stirring time was increased to $15 \mathrm{~min}$ and the equilibrium condition reached.

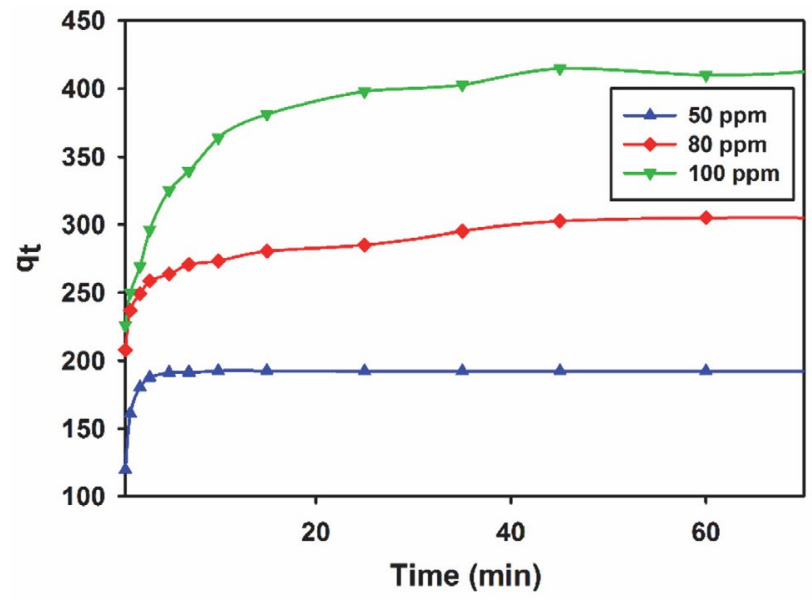

Figure 8. The effect of contact time on the bioreactor performance.

\section{4. The Effect of Electrolyte on Removal Rate}

The effect of electrolyte concentration (adjusted by $\mathrm{KCl}$ ) on the adsorption rate of $\mathrm{Ni}$ (II) was studied. As can be seen in Figure 9, the adsorption efficiency of Ni (II) decreased within the concentration range of $0.0-1 \mathrm{~mol} \cdot \mathrm{L}^{-1}$ of $\mathrm{NaCl}$ in the test solution. At higher concentration, nickel removal efficiency was decreased. Besides, concentration rate of 0.0 mol. $\mathrm{L}^{-1}$ (91.98 \% removal) was used for further evaluations.

\section{5. The Effect of Solution Temperature on Removal Rate}

The effect of temperature on the adsorption rate of $\mathrm{Ni}$ (II) was examined within the temperature range of (5 to 


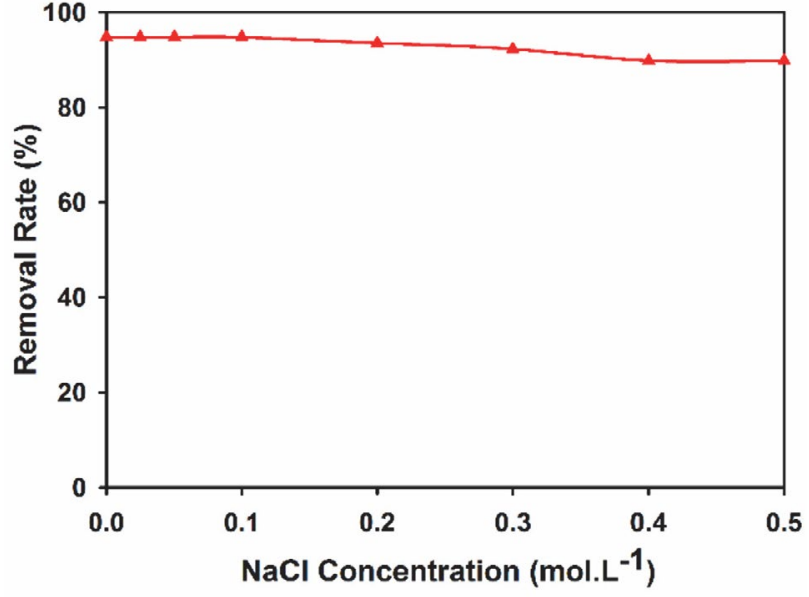

Figure 9. The effect of electrolyte on the bioreactor performance.

60) ${ }^{\circ} \mathrm{C}$. Achieved results indicated that the adsorption rate of $\mathrm{Ni}$ (II) in a $50 \mathrm{ml}$ solution by usage of Kombucha at the $\mathrm{pH}$ of 7 is constant versus variation of temperature. Besides, at higher temperatures, the dye removal efficiency was decreased. Furthermore, the temperature value of $25{ }^{\circ} \mathrm{C}(94.5 \%$ removal) was used for further works. In addition, the effect of contact time on the nickel (II) removal rate and final adsorbent on Kombucha Scoby can be seen in Figure 10.

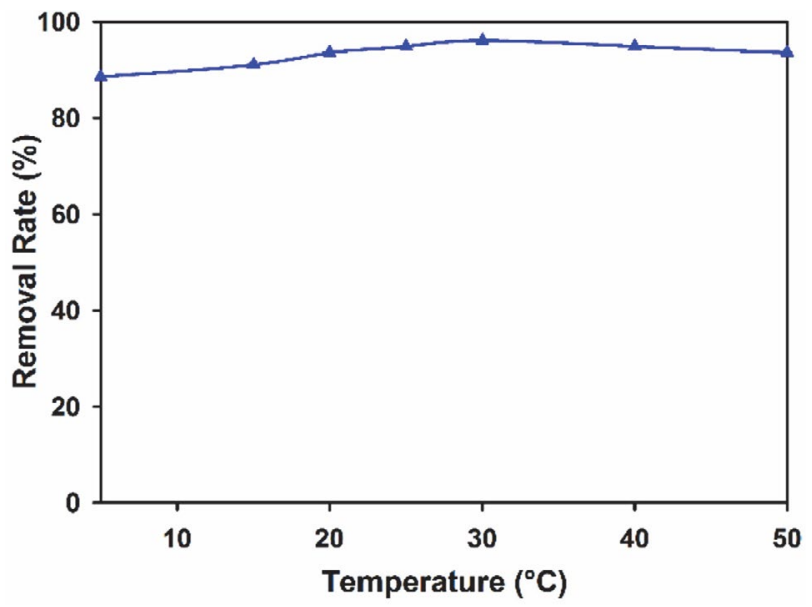

Figure 10. The effect of solution temperature on the bioreactor performance.

\section{6. Isothermal Adsorption Modeling}

The capacities of Kombucha Scoby for adsorption of $\mathrm{Ni}$ (II) ions were examined by measuring the initial and final concentration of $\mathrm{Ni}$ (II) at the $\mathrm{pH}$ and temperature values of 7 and $25{ }^{\circ} \mathrm{C}$ in a batch bioreactor system, respectively. Both Langmuir and Freundlich adsorption isotherms were used to normalize the adsorption data. The correlation of ion adsorption data with the Langmuir isotherm model was higher (with $\mathrm{R}^{2}$ values of 0.9992 ) than the Freundlich model $\left(R^{2}=0.9522\right)$. This implies mono- layer absorption of nickel ions onto active sites of biosorbent.

Besides, the maximum predictable adsorption capacity of $\mathrm{Ni}$ (II) ions is defined to be 454.54 , a view of isothermal adsorption modelling results can be seen in Figure 11 .

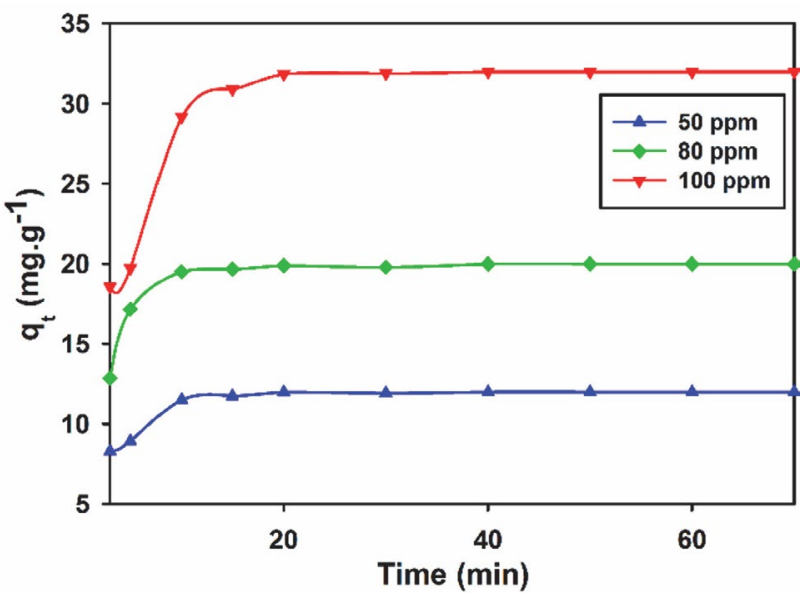

Figure 11. Isothermal adsorption modeling results.

\section{7. Kinetic Modelling of Adsorption}

To describe the adsorption rate and performance of Kombucha Scoby, the data obtained from adsorption kinetic experiments were evaluated using pseudo first and second-order reaction rate models that give a summary of these models and constants along with the determination coefficients for the linear regression plot of the testing ion. As shown in Figure 12 and 13, higher values of $R^{2}$ were obtained for pseudo second-order adsorption rate model, indicating that the adsorption rate of Ni (II) on to the Kombucha Scoby can be described better, by using of the pseudo-second order than the first order. This indicates the mechanism of chemical adsorption.

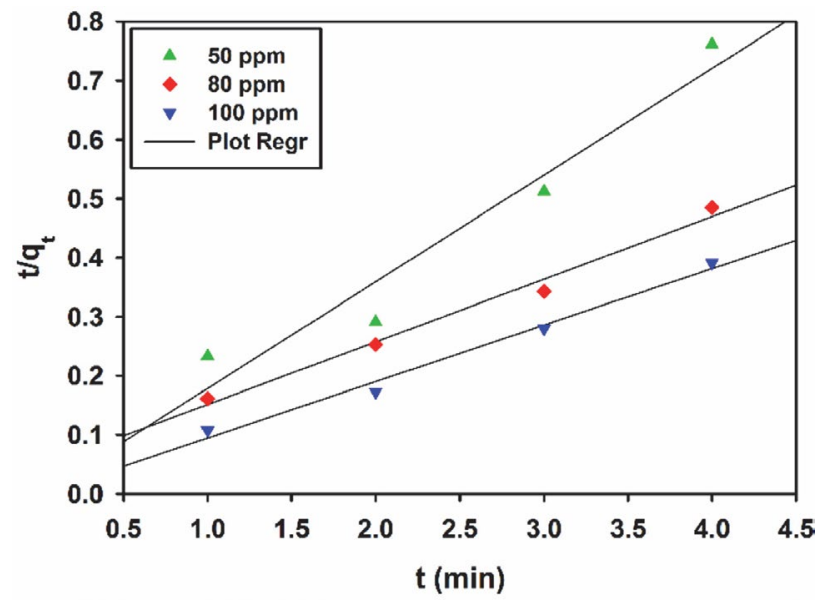

Figure 12. Results of the pseudo first-order reaction rate model. 


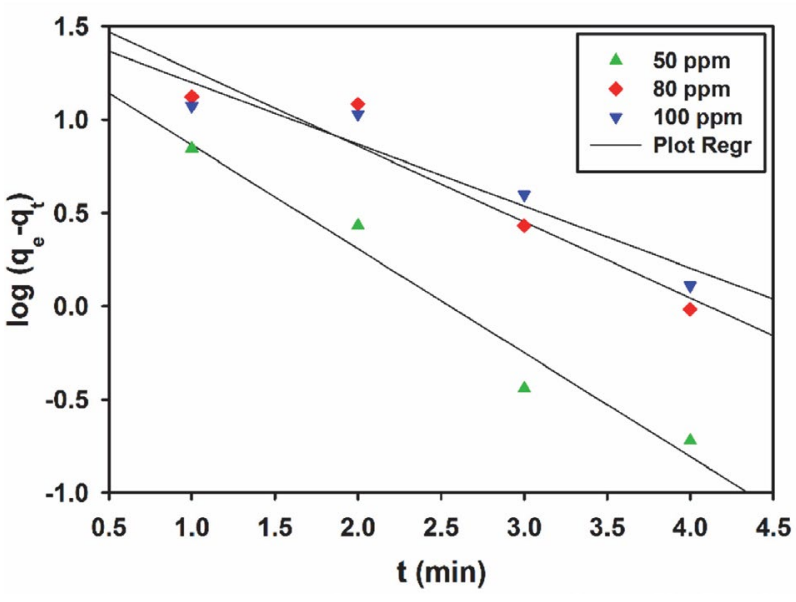

Figure 13. Results of the pseudo second-order rate rather than the first-order model.

\section{8. Adsorption Mechanism}

Based on the results of isotherm and kinetic models analysis, the mechanism of adsorption for the removal of $\mathrm{Ni}$ ions can be suggested. The Freundlich isotherm model shows a deviation from straight line indicating that intra-particle diffusion is not the rate-limiting step of the adsorption mechanism. Meanwhile, the kinetic modelling results suggest the chemical sorption mechanism is dominated in the adsorption process.

Since kombucha is a complex biological material, it operates variety of mechanisms under given conditions. The presence of materials with diverse structures in kambucha presented many functional groups (carboxyl, hydroxyl, amino, etc.) embedded on the surface which be able to interact with nickel ions and responsible for binding metal ions onto kambucha. In this regard, different mechanisms may be involved including ion-exchange, surface complexation, electrostatic interactions, etc. however, many parameters including $\mathrm{pH}$ and temperature can alter the adsorption mechanism of ions onto the surface.

\section{Conclusions}

In this study, Kombucha Scoby was used as an applicatory adsorbent for the removal of Nickel (II) particles. The effects of $\mathrm{pH}$, adsorbent dosage, temperature and time on the adsorption rate were studied. Besides, high adsorption capacity was obtained at low $\mathrm{pH}$ values. Furthermore, the adsorption kinetics and equilibrium data fit well with the pseudo second-order model and Langmuir model respectively. Moreover, usage of Kombucha Scoby in a bioreactor with 4 adsorption cycles and at $\mathrm{pH}=7$, indicated that this bacteria is very effective for removal of $\mathrm{Ni}$ (II) ions from aqueous solution. By comparison of this method with the conventional activated sludge system, the Kombucha Scoby system requires smaller bacteria area and produces a better quality treated water reusable in the industry. With the obvious advantages of the bioreactor technology, it shall gradually replace the conventional activated sludge system in large industrial plants. Besides, by usage of this bacteria, not only the Ni particles can be removed from the suspension but also some products such as alcohol (usually under $2.5 \%$ ), substantial acetic acid (vinegar), ethyl acetate, glucuronic acid and lactic acid can be added to the suspension. In fact, further evaluations showed that low cost Kombucha system can remove the Nickel (II) of about $94.5 \%$, while along with antimicrobial performance of kombucha system, this proposed method can be adapted for waste water purification and restoration of polluted environment via cost affordable method.

\section{References}

1. P. Aikpokpodion, R. Ipinmoroti, S. Omotoso, Aejts. 2010, 2, 72-82.

2. F. S. Khoo, H. Esmaeili, J. Serb. Chem. Soc. 2018, 83, 237-249 DOI:10.2298/JSC170704098S

3. S. M., Mousavi, S. A. Hashemi, A. M. Amani, H. Saed, S. Jahandideh, F. Mojoudi, Polymers from Renewable Resources. 2017, 8, 177-196. DOI:10.1177/204124791700800403

4. N. Goudarzian, Z. Sadeghi, S. M. Mousavi, S. A. Hashemi, N. Banaei, Ijser. 2017, 8, 1275-1279

5. K. Kadirvelu, K. Thamaraiselvi, C. Namasivayam, Sep. Purif. Technol. 2001, 24, 497-505.

DOI:10.1016/S1383-5866(01)00149-6

6. S. M. Mousavi, S. A. Hashemi, A. M. Amani, H. Esmaeili, Y. Ghasemi, A. Babapoor, O. Arjomand, PCR. 2018, 6, 759-771.

7. T. W. Tee, A. R. M. Khan, Environ. Technol. 1988, 9, 12231232. DOI:10.1080/09593338809384685

8. S. M. Mousavi, S.A. Hashemi, O. Arjmand, A. Babapoor, A. M. Amani, F. Mojoudi, H. Esmaeili, S. Jahandideh, Acta Chim. Slov. 2018, 65, 882-894. DOI:10.17344/acsi.2018.4537

9. H. Hasar, J. Hazard. Mater. 2003, 97, 49-57. DOI:10.1016/S0304-3894(02)00237-6

10. W. Tan, S. Ooi, C. Lee, Environ. Technol. 1993, 14, 277-282. DOI: $10.1080 / 09593339309385290$

11. K. Low, C. Lee, S. Wong, Environ. Technol. 1995, 16, 877-883. DOI:10.1080/09593331608616326

12. I. Saucedo, E. Guibal, Ch. Roulph, P. Le Cloirec, Environ. Technol. 1992, 13, 1101-1115. DOI:10.1080/09593339209385250

13. B. S. Zadeh, H. Esmaeili, R. Foroutan, Indonesian Journal of Chemistry. 2018, 18. DOI:10.22146/ijc.28789

14. S. M. Mousavi, H. Esmaeili, O. Arjmand, Sh. Karimi, S. A. Hashemi, Journal of Materials. 2015, 2015, 1-6. DOI: $10.1155 / 2015 / 131957$

15. S. M. Mousavi, S. A. Hashemi, H. Esmaeili, A. M. Amani, F. Mojoudi, Acta Chim. Slov. 2018, 65, 750-756.

DOI: $10.17344 /$ acsi.2018.4536

16. R. Foroutan, H. Esmaeili, M. Abbasi, M. Rezakazemi, M. Mesbah, Environ. Technol. 2018, 39, 2792-2800. 
17. A. Agrawal, K. Sahu, B. Pandey, Colloids Surf. A. 2004, 237, 133-140. DOI:10.1016/j.colsurfa.2004.01.034

18. H. Esmaeili, R. Foroutan, Ijbpas. 2015, 4, 611-619.

19. M. R. Mehrasbi, Z. Farahmandkia, B. Taghibeigloo, A. Taromi, Water Air Soil Pollut. 2009, 199, 343-351. DOI:10.1007/s11270-008-9883-9

20. R. S. D. Castro, L. Caetano, G. Ferreira, P. M. Padilha, M. J. Saeki, L.F. Zara, M. A. U. Martines, G. Castro, R.Ind. Eng. Chem. Res. 2011, 50, 3446v3451. DOI:10.1021/ie101499e

21. X. Li, Y. Tang, X. Cao, D. Lu, F. Luo, W. Shao, Colloids Surf. A. 2008, 317, 512-521. DOI:10.1016/j.colsurfa.2007.11.031

22. H. Z. Shahmohammadi, Removal of low concentrations of cadmium from water using improved rice husk. 2008.

23. F. D. Oliveira, A. C. Soares, O. M. Freitas, S. A. Figueiredo, Global Nest J. 2010, 12, 206-214.

24. I. Maiz, M.V. Esnaola, E. Millan, Sci Total Environ. 1997, 206, 107-115. DOI:10.1016/S0048-9697(97)80002-2

25. L. Norton, K. Baskaran, T. McKenzie, Adv. Environ. Res. 2004, 8, 629-635. DOI:10.1016/S1093-0191(03)00035-2

26. M. Ghaedi, E. Asadpour, A. Vafaie, Bull. Chem. Soc. Jpn. 2006, 79, 432-436. DOI:10.1246/bcsj.79.432

27. M. Ghaedi, F. Ahmadi, Z. Tavakoli, M. Montazerozohori, A. Khanmohammadi, M. Soylak, J. Hazard. Mater. 2008, 152, 1248-1255. DOI:10.1016/j.jhazmat.2007.07.108

28. X. Huang, X. Chang, Q. He, Y. Cui, Y. Zhai. N. Jiang, J. Hazard. Mater. 2008, 157, 154-160.

DOI:10.1016/j.jhazmat.2007.12.113

29. G. Sreeramulu, Y. Zhu, W. Knol, J. Agric. Food Chem. 2000, 48, 2589-2594. DOI:10.1021/jf991333m

30. T. Kappel, R. Anken, Mycologist. 1993, 7, 12-13. DOI:10.1016/S0269-915X(09)80616-2

31. K. H. Steinkraus, Food Control. 1997, 8, 311-317. DOI:10.1016/S0956-7135(97)00050-9

32. M. Sievers, C. Lanini, A. Weber, U. Schuler-Schmid, M. Teuber, Syst. Appl. Microbiol. 1995, 18, 590-594.

DOI:10.1016/S0723-2020(11)80420-0
33. C. Dufresne, E. Farnworth, Food. Res. Int. 2000, 33, 409-421. DOI:10.1016/S0963-9969(00)00067-3

34. G. W. Frank, A. Tyndale, Kombucha: Healthy Beverage and Natural Remedy from the Far East, Its Correct Preparation and Use. Publishing House W. Ennsthaler, 1995.

35. C. Greenwalt, K. Steinkraus, R. Ledford, J. Food Prot. 2000, 63, 976-981. DOI:10.4315/0362-028X-63.7.976

36. C. Greenwalt, R. Ledford, K. Steinkraus, LWT-Food Science and Technology. 1998, 31, 291-296.

DOI:10.1006/fstl.1997.0354

37. G. Sreeramulu, Y. Zhu, W. Knol, Acta Biotechnol. 2001, 21, 49-56. DOI:10.1002/1521-3846(200102)21:1<49::AID-ABIO 49>3.0.CO;2-G

38. C. Hobbs, Kombucha, Tea Mushroom: The Essential Guide. Botanical Press, 1995.

39. E. S. Lončar, S. E. Petrovič, R. V. Malbača, R. M. Verac, Mol. Nutr. Food. Res. 2000, 44, 138-139. DOI:10.1002/(SICI)1521-3803(20000301)44:2<138::AIDFOOD138>3.0.CO;2-\#

40. H. Tietze, Kombucha: The miracle fungus. Harald Tietze Publishing, 1996.

41. I. Jankovic, M. Stojanovic, Mikrobiologija (Yugoslavia), 1994.

42. P. Mayser, S. Fromme, G. Leitzmann, K. Gründer, MYCOSES. 1995, 38, 289-295.

DOI:10.1111/j.1439-0507.1995.tb00410.x

43. C. H. Liu, W. H. Hsu, F. L. Lee, C. C. Liao, Food Microbiol. 1996, 13, 407-415. DOI:10.1006/fmic.1996.0047

44. F. S. Sarvestani, H. Esmaeili, and B. Ramavandi, 3 Biotech. 2016, 6, 251.

45. R. Foroutan, H. Esmaeili, Hossein; S. M. D. Rishehri, F. Sadeghzadeh, S. R. Mirahmadi, M. Kosarifard, B. Ramavandi, Data brief. 2017, 12, 485-492. DOI:10.1016/j.dib.2017.04.031

46. A. Teimouri, H. Esmaeili, R. Foroutan, B. Ramavandi, Korean J Chem Eng. 2018, 35, 479-488.

DOI:10.1007/s11814-017-0311-y

\section{Povzetek}

Kombuča (ang. Kombucha Scoby) imenujemo združbo sestavljeno iz bakterij in kvasovk na nosilcu iz celuloznih vlaken, ki ima edinstvene lastnosti uporabne na mnogih področjih. Poleg antimikrobnih in antitoksičnih lastnosti kombuče, jo lahko uporabimo v reaktorjih za odstranjevanje težkih kovin iz onesnaženih voda. Cilj študije je bil preučiti možnost odstranjevanja $\mathrm{Ni}$ (II) ionov iz odpadnih vod s pomočjo kombuče pri različnih $\mathrm{pH}$ vrednostih, času, temperature, raztopni elektrolitov, volumnu pufra in vrsti. Eksperimenti adsorpcije so pokazali, da je maksimalna kapaciteta vezave Ni (II) ionov dosežena pri $\mathrm{pH}$ vrednosti 7, kontaktnem času $15 \mathrm{~min}$ in temperaturi $25^{\circ} \mathrm{C}$. Pod optimalnimi pogoji se adsorbira $94.5 \% \mathrm{Ni}$ (II) ionov, kar kaže na znaten potencial kombuče pri odstranjevanju težkih kovin. Ravnotežne rezultate lahko učinkovito opišemo z Langmuirjevo izotermo na osnovi česar je bila določena maksimalna kapaciteta vezave, ki znaša $454.54 \mathrm{mg} / \mathrm{g}$ pri $25^{\circ} \mathrm{C}$. Kinetiko adsorpcije Ni (II) ionov na kombučo smo uspešno opisali z modelom pseudo-drugega reda.

Except when otherwise noted, articles in this journal are published under the terms and conditions of the Creative Commons Attribution 4.0 International License 